\section{Roman Khesin-Lur'e}

SIR-Vera Rich, in her comments on the Lenin prizes for science in the Soviet Union (Nature 321, 6; 1986), was very sceptical about the merit of this award given to $\mathrm{Dr} \mathrm{R}$. Khesin-Lur'e, merely because the award citation dated his publications in biochemical genetics from 1960 when "Lysenkoism was then in full swing". Rich also stated that "it would be interesting to know where Khesin Lur'e published his work at that time, and what part, if any, he played in the overthrow of Lysenkoism". Unfortunately, my old friend R.B. Khesin-Lur'e is unable to answer these questions. The prize was given to him posthumously. Because he was indeed a very prominent scientist. I hope that my brief reply may serve as a short obituary.

Roman Beniaminovich Khesin-Lur'e was born in 1922 and graduated from Moscow University as a geneticist in 1945. His PhD study was carried out under the supervision of the prominent Soviet geneticist A.S. Serebrovsky. In 1948, immediately after Lysenko's "coup", Khesin-Lur'e was dismissed from Moscow University. In 1949-53 he worked as an ordinary technician at the Institute of Biological and Medical Chemistry in Moscow, and in 1954-59 as a lecturer in biochemistry at the Medical Institute in Kaunas. In 1959, he started research work as senior scientist in biochemical genetics at the biological division of the Institute of Atomic Energy in Moscow, where Academician Igor Kurchatov gave protection to many Soviet geneticists who were not able to find work in the academy system or in colleges of higher education. From 1978, Khesin-Lur'e (who is better known in Soviet literature simply as Khesin) worked at the Institute of Molecular Genetics of the Academy of Sciences of the USSR and was, in fact, a founder of this institute.

It is enough to look through Chemical Abstracts for 1959-65 to find out that R.B. Khesin was able to publish many of his works during the period of Lysenko's domination. They were published usually in journals, such as Biochimija, Medizinskaya Khimija, Zhurnal Vsesoyznogo Khim. Obshestva and in different volumes, such as Aktual'nye Voprosy Sovremennoi Biokhimii, starting from Vol. 1 in 1959 and covered many subjects relevant to biosynthesis of proteins and nucleic acids. In 1960, Khesin published his well known (in the Soviet Union) book Biokhimija Tsytoplasmy (Biochemistry of Cytoplasm), which was published by the publishing house of the Academy of Sciences of the USSR. Khesin-Lur'e did play a very important role in "the overthrow of Lysenko" and did so primarily by his honest and intensive research in an extremely difficult situation. He died from cancer in 1985, very soon after he was nominated for the Lenin prize.

Lenin prizes in science are not international and the evaluation of scientific merit for them is, of course, a matter for Soviet scientists to decide. The very fact that Vera Rich has apparently never heard the name Khesin-Lur'e before is certainly not sufficient reason to doubt his contribution to science and his integrity as a scientist.

\section{Division of Genetics,}

Zhores A. Medvedev

National Institute for Medical Research, Mill Hill,

London NW7 IAA, UK

\section{Environmentalism}

SiR-David Pearce rightly criticizes the nuclear industry in his review of Tony Hall's book. Nuclear Policy: The History of Nuclear Power in Britain, for having neither the traditions nor the capabilities to handle "environmentalism" when it emerged as a popular and political force. The industry was not alone in failing to appreciate the threat of this movement. It has taken some time for the true motivations of some "environmentalists" to emerge. Many of them seem to be seeking some sort of non-industrial Arcadia irrelevant to the needs of today's world, dominated by the problems of developing countries attempting to achieve some improvement in their living standards in the face of relentless pressures from population growth.

For example, Edward Goldsmith in an editorial in the Ecologist" asks "How are we to power our expanding industrial society?". He considers the prospects for oil, coal and renewable sources of energy and concludes "The answer is that there is no alternative (to nuclear power)... no nuclear power - no industrial society... the nuclear power station has become the symbol of the industrial way of life... The industrial way of life is squalid, mediocre and unfulfilling. Progress is an illusion."

The consequences of such views are well illuminated by J. Gordon Edwards who points to the enormous amount of damage done by so-called environmentalists using as an example the DDT story. where concern about trace quantities of this material has had untold harmful consequences on malaria eradication programmes.

The world's problems may be soluble through the continuing application of science and technology that has already led to dramatic improvements in infant survival, public health and life expectancy, to a transformation of India from a continent threatened by starvation to a net food exporter, and to the harnessing of nuclear energy to enable the world to survive the depletion of its fossil fuel reserves and avoid the risks of climatic change from their consumption. They will not be solved by the pursuit of rural Utopias inconsistent with today's population and its aspirations.

The Chernobyl accident should result in a major re-examination of the safety of nuclear plants throughout the world. We must ensure that the lessons of the accident are learned and applied, as happened, at least in the West, after Three Mile Island. But the predictable calls for a run-down of the world's nuclear programmes as a result of Chernobyl is as sensible as a call for the world to do without agricultural chemicals as a result of Bhopal.

P.A.H. Saunders

Environmental and Medical Sciences

Division,

Harwell Laboratory,

Didcot,

OXON OXII 9PS. UK

\section{Parce D Nuture 320. +113 ( I986)}

Goldsmith E Ecologios 6.3111 [9976)

Gordon Edwards. J Vamre 320, 391 (19)6h)

SIR-The leading article "What future for nuclear power?" (Nature 321, 367; 1986) contained criticisms of Western environmental movements and impugned the motives of their membership.

Surely imprecation via an examination of motives as a substitute for argument is slightly insulting to the readers of Nature or any other journal bent on the promotion of serious discussion.

Apart from the fact that criticism based on an examination of motives is irrefutable in practical terms, it also substitutes mud-slinging for discussion. It is tempting to suggest that the aspiration of the mudslinger is that some of the mud may stick. But mud-slinging merely obscures issues and never contributes to serious debate.

The Western environmentalist movement has raised serious doubts. based on cogent arguments, about the efficacy and safety of nuclear power. It is these arguments that should be addressed: the reasons why the participants raised them. apart from concern with efficacy and safety, are of little significance.

Focusing on this matter, at the expense of arguing your case. results either from the arrogant assumption that environmentalists are of little consequence because of their populist origins and so their views on nuclear power must also be of little consequence. or a tacit recognition that the environmentalist argument presents problems for those who support the nuclear power programme. If the latter. why not admit it. and if the former. shame on you!

\section{Knoll Cottage}

Residential Park.

Winfrith.

Dorchester,

Dorset DT2 8LD. UK
Barrie Pearson 